\title{
Review of the Interaction Between Body Composition and Clinical Outcomes in Metastatic Renal Cell Cancer Treated With Targeted Therapies
}

\author{
Steven M. Yip, Daniel Y.C. Heng, Patricia A. Tang \\ Department of Oncology, University of Calgary, Tom Baker Cancer Centre, Calgary, Alberta, Canada.
}

\begin{abstract}
Treatment of metastatic renal cell cancer (mRCC) currently focuses on inhibition of the vascular endothelial growth factor pathway and the mammalian target of rapamycin (mTOR) pathway. Obesity confers a higher risk of RCC. However, the influence of obesity on clinical outcomes in mRCC in the era of targeted therapy is less clear. This review focuses on the impact of body composition on targeted therapy outcomes in mRCC. The International Metastatic Renal Cell Carcinoma Database Consortium database has the largest series of patients evaluating the impact of body mass index (BMI) on outcomes in mRCC patients treated with targeted therapy. Overall survival was significantly improved in overweight patients $\left(B M I \geq 25 \mathrm{~kg} / \mathrm{m}^{2}\right)$, and this observation was externally validated in patients who participated in Pfizer trials. In contrast, sarcopenia is consistently associated with increased toxicity to inhibitors of angiogenesis and mTOR. Strengthening patients with $\mathrm{mRCC}$ and sarcopenia, through a structured exercise program and dietary intervention, may improve outcomes in mRCC treated with targeted therapies. At the same time, the paradox of obesity being a risk factor for RCC while offering a better overall survival in response to targeted therapy needs to be further evaluated.
\end{abstract}

Keywords: adiposity; body composition; obesity; renal cell carcinoma; sarcopenia; targeted therapy; toxicity

Received: 10 October 2015; Accepted after revision: 09 February 2016; Published: 22 March 2016.

Author for correspondence: Patricia Tang, MD, 133129 St NW, Calgary, AB T2N 4N2, Canada. Email: Patricia.tang@ahs.ca

How to cite: Yip SM, Heng DYC, Tang PA. Review of the interaction between body composition and clinical outcomes in metastatic renal cell cancer treated with targeted therapies. J Kidney Cancer VHL 2016;3(1):12-22. Doi: http://dx.doi.org/10.15586/jkcvhl.2016.45

Copyright: The Authors.

License: This open access article is licensed under Creative Commons Attribution 4.0 International (CC BY 4.0). http://creativecommons.org/licenses/by/4.0

\section{Introduction}

Treatment of metastatic renal cell cancer (mRCC) currently focuses on inhibition of the vascular endothelial growth factor
(VEGF) pathway and the mammalian target of rapamycin (mTOR) pathway. Although predictive biomarkers for targeted therapy 
Table 1. Comparison of multivariable prognostic factor models in metastatic renal cell carcinoma

\begin{tabular}{|c|c|c|}
\hline Model & MSKCC & IMDC criteria \\
\hline & Motzer et al. $(2,3)$ & Heng et al. (1) \\
\hline Patient population & $\begin{array}{l}463 \text { patients treated with } \\
\text { interferon alpha on prospective } \\
\text { clinical trials }\end{array}$ & $\begin{array}{l}645 \text { patients treated with } \\
\text { sunitinib, sorafenib, } \\
\text { bevacizumab at multiple } \\
\text { American centers }\end{array}$ \\
\hline \multirow[t]{6}{*}{ Prognostic factors } & KPS $<80 \%$ & KPS $<80 \%$ \\
\hline & $\mathrm{LDH}>1.5 \times \mathrm{ULN}$ & Corrected calcium > ULN \\
\hline & Corrected calcium $>10 \mathrm{mg} / \mathrm{dL}$ & Hemoglobin < LLN \\
\hline & $(2.5 \mathrm{mmol} / \mathrm{L})$ & Disease-free interval $<1$ year \\
\hline & Hemoglobin < LLN & Neutrophils > ULN \\
\hline & Disease-free interval $<1$ year & Platelets > ULN \\
\hline Favorable risk & No risk factors, mOS 30 months & No risk factors, mOS not reached \\
\hline Intermediate risk & 1 risk factor, mOS 14 months & $1-2$ risk factors, mOS 27 months \\
\hline Poor risk & $2-3$ risk factors, mOS 5 months & $\begin{array}{l}3 \text { or more risk factors, } \mathrm{mOS} 8.8 \\
\text { months }\end{array}$ \\
\hline
\end{tabular}

IMDC: International Metastatic Renal Cell Carcinoma Database Consortium; KPS: Karnofsky performance status; LDH: Lactate dehydrogenase; LLN: Lower limit of normal; mOS: median overall survival; MSKCC: Memorial Sloan-Kettering Cancer Center; ULN: Upper limit of normal.

have yet to be validated, there are prognostic models that can stratify mRCC patients into low-, intermediate-, and highrisk groups. Two commonly used models include the International Metastatic Renal Cell Carcinoma Database Consortium (IMDC) model (1) and the Memorial SloanKettering Cancer Center (MSKCC) criteria $(2,3)$ (Table 1).

Obesity confers a higher risk of RCC (47); however, the influence of obesity on clinical outcomes in $\mathrm{mRCC}$ in the era of targeted therapy is less clear. The World Health Organization utilizes body mass index (BMI; weight divided by height squared) to define the terms "overweight" (BMI 25.0-29.9 kg/m²) and "obesity" $\left(\mathrm{BMI} \geq 30 \mathrm{~kg} / \mathrm{m}^{2}\right)$ (8). However, BMI does not accurately reflect body composition, the proportion of lean tissue to fat; nor does BMI account for sarcopenia, the loss of skeletal muscle tissue. Computed tomography (CT) is often used to assess response to therapy as part of routine care. Cross-sectional imaging can be utilized to quantify skeletal muscle density (SMD) and adipose tissue. In addition, relative distribution of fat can be localized to the visceral or subcutaneous compartments (visceral fat area [VFA] and superficial fat area [SFA]).

Higher BMI may negatively influence outcomes through commonly associated comorbidities of diabetes and cardiovascular disease (9). It may alter drug concentrations and pharmacokinetics of targeted therapies that are dosed independent of weight. Obesity may activate oncogenic pathways and create an inflammatory state. This is postulated to occur via elevations in interleukins (IL-6, IL-1 $\beta$, and IL-1 receptor antagonist), tumor necrosis factor, and $\mathrm{C}$ reactive protein (10). Furthermore, a proangiogenic state is created by the production of factors such as VEGF and leptin by adipose tissue (11). An obese body composition also can promote and activate the mTOR pathway through reactive oxygen species (12), as well as elevated levels of insulin and insulin-like growth factor (13).

Obesity is paradoxically associated with better prognosis, particularly in the setting of nephrectomized patients with $\operatorname{RCC}(14,15)$. Table 2 summarizes the findings of studies, which examine this relationship between survival rates in mRCC and body composition metrics. This review paper will focus on the impact of 
Table 2. Retrospective studies evaluating the impact of body composition on outcome in metastatic renal cell carcinoma patients treated with targeted therapies

\begin{tabular}{|l|l|l|}
\hline Study population & $\begin{array}{l}\text { Body composition } \\
\text { cutpoint for } \\
\text { obesity }\end{array}$ & Impact on clinical outcomes \\
\hline $\begin{array}{l}\text { Choueiri et al. } 475 \text { North } \\
\begin{array}{l}\text { American patients included in } \\
\text { the IMDC database (16) }\end{array}\end{array}$ & BMI $\geq 30 \mathrm{~kg} / \mathrm{m}^{2}$ & $\begin{array}{l}\text { High BMI associated with } \\
\text { improved OS }\end{array}$ \\
\hline Albiges et al. 1,975 patients (17) & BMI $\geq 25 \mathrm{~kg} / \mathrm{m}^{2}$ & $\begin{array}{l}\text { HR } 0.67 \\
\text { (95\% CI 0.49-0.91, } \mathrm{p}=0.01) \\
\text { improved median OS }(25.6 \mathrm{vs} \\
17.1 \text { months, } \mathrm{p}<0.0001)\end{array}$ \\
\hline $\begin{array}{l}\text { Albiges et al. } 4,657 \text { patients } \\
\text { from Pfizer trials (18) }\end{array}$ & BMI $\geq 25 \mathrm{~kg} / \mathrm{m}^{2}$ & $\begin{array}{l}\text { High BMI: improved OS (HR } \\
0.830, \mathrm{p}=0.0008,95 \% \mathrm{CI}\end{array}$ \\
& & $0.743-0.925)$
\end{tabular}

BMI: body mass index; BSA: body surface area; HR: hazard ratio; OS: overall survival; $\mathrm{CI}$ : confidence interval.

body composition on targeted therapy outcomes in mRCC.

\section{Literature search strategy}

A PubMed and Medline literature search was performed for the time period 1994 to 2015 with the following search terms:

sarcopen*, BMI, body mass, cachexia, BSA, body surface area, body composition, renal cell ca*, RCC, kidney cancer, prognos*, outcome*, response, predict*, mTOR, everolimus, sirolimus, sunitinib, PD1, PDL1. Additionally, American Society of Clinical Oncology meeting proceedings were searched with the following search terms: BMI, body, BSA, renal cell. Articles in any language were included, and all levels of evidence were considered. The retrieved articles' relevant references were also reviewed for possible inclusion. Eleven articles (eight published, three abstracts) evaluated body composition as a prognostic factor for targeted therapy outcomes in mRCC.

\section{Impact of BMI on outcomes}

Body composition and its potential influence on targeted therapy outcomes were initially assessed in a retrospective study of $475 \mathrm{mRCC}$ patients treated with antiangiogenic therapy. Choueiri et al. (16) identified that obesity (BMI $>30 \mathrm{~kg} / \mathrm{m}^{2}$ ) was independently associated with greater overall survival (OS) (hazard ratio [HR] $0.67,95 \%$ confidence interval [CI] 0.49$0.91, \mathrm{p}=0.01$ ), after adjusting for the IMDC model criteria. The IMDC updated this analysis in a larger dataset of 1,975 patients treated with targeted therapy (17). Overweight or obese patients (BMI $\geq 25$ $\mathrm{kg} / \mathrm{m}^{2}$ ) had a significantly longer median OS compared with underweight or normal patients (25.6 vs 17.1 months, $\mathrm{p}<0.0001)$, which remained significant after adjusting for IMDC model criteria.

This finding was externally validated in a cohort of 4,657 mRCC patients on phase II and III Pfizer trials from 2003 to 2013 (18). Overweight or obese patients (BMI $\geq 25$ $\mathrm{kg} / \mathrm{m}^{2}$ ) had a longer OS, in comparison with the low BMI group (BMI $<25 \mathrm{~kg} / \mathrm{m}^{2}$ ) (23.4 vs 14.5 months, HR $0.830,95 \%$ CI $0.743-0.925, \mathrm{p}=0.0008$ ), while controlling for the IMDC prognostic risk criteria. Similarly, high BMI was associated with improved progression-free survival (PFS) (HR 0.821, 95\% CI 0.746-0.903, p < 0.0001 ) and response rate (odds ratio $1.527,95 \%$ CI $1.258-1.855, \mathrm{p}<0.001)$, in contrast to low BMI. Interestingly, the results were similar when stratified by line of therapy. The favorable outcome associated with elevated BMI was observed only in clear cell mRCC, when stratified by histology. 
There was question of whether tolerability of therapy in higher BMI patients played a role in producing these findings. However, in the IMDC dataset, rates of early discontinuation due to adverse events did not differ between the two BMI groups, and therefore this was unlikely a cause of bias (17). Additionally, the toxicity patterns were similar in the high- and low-BMI groups in the external Pfizer validation set (18).

The biologic rationale for the association between BMI and outcomes is not clear. Fatty acid synthase (FASN) is a key enzyme involved in the production of fatty acids. FASN has emerged as a metabolic oncogene with an important role in tumor growth and survival (19). There was a trend to improved $\mathrm{OS}$ in the elevated BMI group $(\mathrm{p}=0.07)$ in the Cancer Genome Atlas clear cell mRCC dataset $(\mathrm{n}=61)$ (18). High BMI was associated with low FASN gene expression $(\mathrm{p}=0.034)$, and FASN expression (using the median as a cutpoint) was inversely associated with OS $(\mathrm{p}=0.002)$. FASN gene was evaluated using immunohistochemistry (IHC) in the IMDC biospecimen cohort (17). Median OS was significantly improved in FASN IHC negative compared with positive patients (27.5 vs 14.5 months, $\mathrm{p}=0.005$ ). FASN metabolism may contribute to the development of mRCC and therefore may represent a novel therapeutic target. These results are hypothesis-generating.

\section{Volumetric assessment of body composition}

BMI is a relatively crude measurement of body composition. Other groups have evaluated more granular metrics of body composition such as volumetric assessment of fat and muscle (Table 3). Software programs can be used to identify the visceral and subcutaneous visceral adipose compartments using Houndsfield units at specific landmarks on $\mathrm{CT}$, followed by calculation of the cross-sectional area. In contrast to the IMDC data, BMI was not prognostic in other smaller retrospective studies that incorporate these volumetric assessments (20-22). Steffens et al. (20) evaluated the impact of baseline BMI, body surface area $\left(\mathrm{BSA}, \mathrm{m}^{2}\right), \mathrm{VFA}$, and SFA in 116 mRCC patients. VFA and SFA were calculated with Image J software using the umbilicus as the landmark. The cutoffs used were a BMI $\geq 30 \mathrm{~kg} / \mathrm{m}^{2}$, a BSA above the European average $>1.74$ for women and BSA $>1.98$ for men, and finally an SFA or a VFA above the median of the patient cohort. On multivariate Cox regression analysis incorporating histological subtype and MSKCC status, there was no significant association between PFS and OS with elevated BMI and BSA. Elevated SFA and VFA were independently associated with improved OS and PFS (SFA: HR 3.41, 95\% CI 1.61-7.25, $\mathrm{p}=0.001$; VFA: HR 2.97, 95\% CI $1.36-6.47, \mathrm{p}=0.006$ ).

Ladoire et al. (21) evaluated the prognostic impact of BMI, SFA, and VFA in French patients with mRCC using similar methods as Steffens et al. The median was used to dichotomize SFA and VFA values into high versus low. High VFA was associated with significantly shorter time to progression and OS (HR 6.26, 95\% CI 2.29-17.08, p < 0.001) in patients treated with antiangiogenic drugs $(n=64)$ but not in patients treated with cytokines $(\mathrm{n}=49)$, on multivariate analysis, including MSKCC group. An obese BMI $\left(>30 \mathrm{~kg} / \mathrm{m}^{2}\right)$ and high SFA were not prognostic. Ladoire et al. suggested that high VFA was a predictive factor since it was associated with worse outcomes for patients treated with antiangiogenic therapy but not cytokines. These results differ from the larger IMDC dataset, in which overweight or obese patients (BMI $\geq 25 \mathrm{~kg} / \mathrm{m}^{2}$ ) had a significantly longer median OS compared with underweight or normal patients (17).

$\mathrm{Gu}$ et al. (22) retrospectively assessed BMI, BSA, visceral adipose tissue (VAT) index, subcutaneous adipose tissue (SAT), and SMD in mRCC patients treated with VEGF and mTOR therapies $(n=124)$. SAT and VAT were measured with $\mathrm{CT}$ at the level of the third lumbar vertebra and calculated with Image J software. Based on Cox regression modeling adjusting for age, sex, and IMDC criteria, both VAT and SAT indices were significantly associated with prolonged OS (VAT: HR 0.981; 95\% CI 0.969-0.993, $\mathrm{p}=$ 0.002; SAT: HR 0.987, 95\% CI: 0.974-1.000, $\mathrm{p}=0.048)$. However, no significant association was found between OS and BMI $(p=0.121)$, nor BSA $(p=0.335)$. Sarcopenia, or a depletion of skeletal muscle, can occur independent of adiposity. SMD had no significant association with OS (HR 1.000, 95\% CI 0.986-1.013, $\mathrm{p}=0.950$ ). 
Table 3. Influence of volumetric assessments of body composition on clinical outcomes in $\mathrm{RCC}$

\begin{tabular}{|c|c|c|c|c|c|}
\hline \multirow[t]{2}{*}{ Study } & \multirow{2}{*}{$\begin{array}{l}\text { Body } \\
\text { composition } \\
\text { cutpoint }\end{array}$} & \multicolumn{4}{|c|}{ Impact of body composition on outcomes } \\
\hline & & $\begin{array}{l}\text { Elevated } \\
\text { body mass } \\
\text { index (BMI) }\end{array}$ & $\begin{array}{l}\text { Elevated } \\
\text { superficial } \\
\text { fat area } \\
\text { (SFA) }\end{array}$ & $\begin{array}{l}\text { Elevated } \\
\text { visceral fat } \\
\text { area (VAT) }\end{array}$ & $\begin{array}{l}\text { Sarcopenia } \\
\text { or skeletal } \\
\text { muscle } \\
\text { density } \\
\text { (SMD) }\end{array}$ \\
\hline $\begin{array}{l}\text { Steffens et al. } \\
116 \text { European } \\
\text { patients (20). } \\
\text { VFA and SFA } \\
\text { were } \\
\text { computed with } \\
\text { ImageJ } \\
\text { software at the } \\
\text { level of the } \\
\text { umbilicus }\end{array}$ & $\begin{array}{l}\mathrm{BMI} \geq 30 \\
\mathrm{~kg} / \mathrm{m}^{2}, \mathrm{BSA} \\
\text { above the } \\
\text { European } \\
\text { average }> \\
1.74 \text { for } \\
\text { women and } \\
\mathrm{BSA}>1.98 \\
\text { for men. SFA } \\
\text { or VFA above } \\
\text { the median of } \\
\text { the patient } \\
\text { cohort }\end{array}$ & $\begin{array}{l}\text { Not } \\
\text { prognostic }\end{array}$ & $\begin{array}{l}\text { High SFA, } \\
\text { improved } \\
\text { OS. HR } 3.41 \\
(95 \% \text { CI } \\
1.61-7.25 \\
\text { p }=0.001)\end{array}$ & $\begin{array}{l}\text { High VFA, } \\
\text { improved } \\
\text { OS. HR } 2.97 \\
(95 \% \text { CI } \\
1.36-6.47 \\
\text { p }=0.006)\end{array}$ & N/A \\
\hline $\begin{array}{l}\text { Ladoire et al. } \\
64 \text { European } \\
\text { patients }(21) \text {. } \\
\text { Baseline VFA } \\
\text { and SFA were } \\
\text { calculated } \\
\text { with CT at the } \\
\text { level of the } \\
\text { umbilicus and } \\
\text { calculated } \\
\text { with ImageJ } \\
\text { software }\end{array}$ & $\begin{array}{l}\mathrm{BMI}>30 \\
\mathrm{~kg} / \mathrm{m}^{2}, \mathrm{SFA}> \\
\text { median, } \mathrm{VFA} \\
>\text { median }\end{array}$ & $\begin{array}{l}\text { Not } \\
\text { prognostic }\end{array}$ & $\begin{array}{l}\text { High SFA } \\
\text { not } \\
\text { prognostic }\end{array}$ & $\begin{array}{l}\text { High VFA } \\
\text { associated } \\
\text { with shorter } \\
\text { OS in } \\
\text { patients } \\
\text { treated with } \\
\text { VEGF } \\
\text { inhibitors. } \\
\text { HR } 6.26 \\
(95 \% \text { CI } \\
2.29-17.08, \\
\text { p }<0.001)\end{array}$ & N/A \\
\hline $\begin{array}{l}\text { Gu et al. } 124 \\
\text { Chinese } \\
\text { patients (22). } \\
\text { SAT and VAT } \\
\text { measured with } \\
\text { CT at L3, and } \\
\text { calculated } \\
\text { with ImageJ } \\
\text { software }\end{array}$ & $\begin{array}{l}\text { High VAT } \\
33.3 \mathrm{~cm}^{2} / \mathrm{m}^{2}\end{array}$ & $\begin{array}{l}\text { Not } \\
\text { prognostic }\end{array}$ & $\begin{array}{l}\text { SAT } \\
\text { associated } \\
\text { with } \\
\text { improved } \\
\text { OS. } \\
\text { HR } 0.987 \\
(95 \% \text { CI } \\
0.974- \\
1.000, \\
\text { p }=0.048)\end{array}$ & $\begin{array}{l}\text { High VAT } \\
\text { associated } \\
\text { with } \\
\text { improved } \\
\text { OS. } \\
\text { HR } 0.981 \\
(95 \% \text { CI } \\
0.969- \\
0.993 \text {, } \\
\text { p = 0.002) }\end{array}$ & $\begin{array}{l}\text { Not } \\
\text { prognostic }\end{array}$ \\
\hline
\end{tabular}


Table 3. (Continued)

\begin{tabular}{|c|c|c|c|c|c|}
\hline \multirow{2}{*}{ Study } & \multirow{2}{*}{$\begin{array}{l}\text { Body } \\
\text { composition } \\
\text { cutpoint }\end{array}$} & \multicolumn{4}{|c|}{ Impact of body composition on outcomes } \\
\hline & & $\begin{array}{l}\text { Elevated } \\
\text { body mass } \\
\text { index (BMI) }\end{array}$ & $\begin{array}{l}\text { Elevated } \\
\text { superficial } \\
\text { fat area } \\
\text { (SFA) }\end{array}$ & $\begin{array}{l}\text { Elevated } \\
\text { visceral fat } \\
\text { area (VAT) }\end{array}$ & $\begin{array}{l}\text { Sarcopenia } \\
\text { or skeletal } \\
\text { muscle } \\
\text { density } \\
\text { (SMD) }\end{array}$ \\
\hline \multicolumn{6}{|c|}{ Studies Focused on Sarcopenia } \\
\hline $\begin{array}{l}\text { Antoun et al. } \\
149 \text { European } \\
\text { and Canadian } \\
\text { patients (23). } \\
\text { Skeletal mass } \\
\text { density } \\
\text { assessed by } \\
\text { CT } \\
\text { SliceOMatic } \\
\text { software at L3 }\end{array}$ & $\begin{array}{l}\text { Sarcopenia: } \\
\text { below the } \\
\text { median for } \\
\text { patients of } \\
\text { the same sex } \\
\text { within the } \\
\text { study } \\
\text { population }\end{array}$ & $\begin{array}{l}\text { Not } \\
\text { prognostic }\end{array}$ & $\begin{array}{l}\text { SAT not } \\
\text { prognostic }\end{array}$ & $\begin{array}{l}\text { VAT not } \\
\text { prognostic }\end{array}$ & $\begin{array}{l}\text { Shorter OS } \\
(1 / 2) \text { in } \\
\text { patients of low } \\
\text { SMD } \\
\text { compared } \\
\text { with high } \\
\text { SMD (14 vs } \\
29 \text { months, } \\
\text { p = 0.001). } \\
\text { Low SMD OS. } \\
\text { HR } 1.9 \text { (95\% } \\
\text { CI } 1.3-2.9)\end{array}$ \\
\hline $\begin{array}{l}\text { Antoun et al. } \\
55 \text { European } \\
\text { and Canadian } \\
\text { patients } \\
\text { treated with } \\
\text { sorafenib (24). } \\
\text { CT: volumetric } \\
\text { assessment at } \\
\text { the L3 with } \\
\text { SliceOMatic } \\
\text { software }\end{array}$ & $\begin{array}{l}\text { Sarcopenia: } \\
\text { more than } \\
\text { two standard } \\
\text { deviations } \\
\text { below } \\
\text { average on } \\
\text { volumetric } \\
\text { assessment } \\
\text { at L3 }\end{array}$ & $\begin{array}{l}\text { Mean BMI of } \\
\text { patients with } \\
\text { DLT } \\
\text { significantly } \\
\text { lower than } \\
\text { patients who } \\
\text { tolerated full } \\
\text { dose }(23.1 \mathrm{vs} \\
26.0 \mathrm{~kg} / \mathrm{m}^{2} \text {, } \\
\mathrm{p}<0.03)\end{array}$ & $\mathrm{N} / \mathrm{A}$ & $\mathrm{N} / \mathrm{A}$ & $\begin{array}{l}\text { Males with } \\
\text { sarcopenia } \\
\text { more likely to } \\
\text { experience } \\
\text { DLT } \\
\text { compared } \\
\text { with } \\
\text { nonsarcopenic } \\
(37 \% \text { vs } 5 \% \text {, } \\
\text { p < 0.04) }\end{array}$ \\
\hline $\begin{array}{l}\text { McCabe et al. } \\
112 \text { European } \\
\text { patients (26). } \\
\text { Sarcopenia } \\
\text { was assessed } \\
\text { using } \\
\text { Appendicular } \\
\text { Skeletal } \\
\text { Muscle Index } \\
\text { (ASMI), } \\
\text { measuring at } \\
\text { the L3 } \\
\text { landmark on } \\
\text { CT }\end{array}$ & $\begin{array}{l}\text { Sarcopenia } \\
\text { defined as } \\
\text { ASMI }<7.26 \\
\mathrm{~kg} / \mathrm{m}^{2} \text { for } \\
\text { males and } \\
<5.45 \mathrm{~kg} / \mathrm{m}^{2} \\
\text { for females }\end{array}$ & $\mathrm{N} / \mathrm{A}$ & $\mathrm{N} / \mathrm{A}$ & $\mathrm{N} / \mathrm{A}$ & $\begin{array}{l}\text { Sarcopenic } \\
\text { patients more } \\
\text { likely to } \\
\text { experience } \\
\text { severe } \\
\text { treatment- } \\
\text { related } \\
\text { toxicity } \\
\text { compared } \\
\text { with } \\
\text { nonsarcopenic } \\
\text { (Pearson } \\
\text { chi-square } \\
\text { value } 12.82, \\
\mathrm{p}=0.001 \text { ) }\end{array}$ \\
\hline
\end{tabular}


Table 3. (Continued)

\begin{tabular}{|c|c|c|c|c|c|}
\hline \multirow[t]{2}{*}{ Study } & \multirow{2}{*}{$\begin{array}{l}\text { Body } \\
\text { composition } \\
\text { cutpoint }\end{array}$} & \multicolumn{4}{|c|}{ Impact of body composition on outcomes } \\
\hline & & $\begin{array}{l}\text { Elevated } \\
\text { body mass } \\
\text { index (BMI) }\end{array}$ & $\begin{array}{l}\text { Elevated } \\
\text { superficial } \\
\text { fat area } \\
\text { (SFA) }\end{array}$ & $\begin{array}{l}\text { Elevated } \\
\text { visceral fat } \\
\text { area (VAT) }\end{array}$ & $\begin{array}{l}\text { Sarcopenia or } \\
\text { skeletal } \\
\text { muscle } \\
\text { density (SMD) }\end{array}$ \\
\hline $\begin{array}{l}\text { Huillard et al. } \\
61 \text { European } \\
\text { patients } \\
\text { receiving } \\
\text { Sunitinib } \\
\text { (27). } \\
\text { Sarcopenia } \\
\text { was assessed } \\
\text { using L3 } \\
\text { landmark on } \\
\text { CT, using } \\
\text { software } \\
\text { ImageJ } \\
\text { software } \\
\text { v1.42q }\end{array}$ & $\begin{array}{l}\text { Sarcopenia } \\
\text { defined using } \\
\text { the L3 } \\
\text { landmark on } \\
\mathrm{CT} \text {, with sex- } \\
\text { specific cutoff } \\
\text { values of } \\
55.4 \mathrm{~cm}^{2} / \mathrm{m}^{2} \\
\text { for } \mathrm{males} \mathrm{and} \\
38.9 \mathrm{~cm}^{2} / \mathrm{m}^{2} \\
\text { for females }\end{array}$ & $\begin{array}{l}\text { Not } \\
\text { prognostic }\end{array}$ & $\mathrm{N} / \mathrm{A}$ & $\mathrm{N} / \mathrm{A}$ & $\begin{array}{l}\text { Sarcopenics } \\
\text { with BMI }<25 \\
\text { more likely to } \\
\text { experience DLT } \\
\text { compared with } \\
\text { nonsarcopenics } \\
\text { with BMI }>25 \\
(50 \% \text { vs } 19.5 \% \text {, } \\
\text { p }=0.01)\end{array}$ \\
\hline $\begin{array}{l}\text { Cushen et al. } \\
55 \text { European } \\
\text { patients } \\
\text { receiving } \\
\text { sunitinib } \\
\text { (28). Skeletal } \\
\text { muscle mass } \\
\text { and } \\
\text { sarcopenia } \\
\text { assessed } \\
\text { using Osiris } \\
\text { image } \\
\text { software and } \\
\text { measured } \\
\text { with CT } \\
\text { images that } \\
\text { extended } \\
\text { from L3 }\end{array}$ & $\begin{array}{l}\text { Sarcopenia } \\
\text { cutoffs } 55.4 \\
\mathrm{~cm}^{2} / \mathrm{m}^{2} \text { for } \\
\text { males and } \\
38.9 \mathrm{~cm}^{2} / \mathrm{m}^{2} \\
\text { for females }\end{array}$ & $\begin{array}{l}\text { Not } \\
\text { prognostic }\end{array}$ & $\mathrm{N} / \mathrm{A}$ & $\mathrm{N} / \mathrm{A}$ & $\begin{array}{l}\text { Patients with } \\
\text { SMM }<25 \text { th } \\
\text { percentile } \\
\text { experienced } \\
\text { more DLT } \\
\text { compared with } \\
\text { those with } \\
\text { SMM }>75 \text { th } \\
\text { percentile } \\
(92 \% \text { vs } 57 \% \text {, } \\
\text { p = 0.05). } \\
\text { Sarcopenia was } \\
\text { not predictive } \\
\text { for early DLTs }\end{array}$ \\
\hline
\end{tabular}

L3: the level of the third lumbar vertebra; BMI: body mass index; BSA: body surface area; CI: confidence interval; DLT: dose-limiting toxicity; HR: hazard ratio; N/A: not available; OS: overall survival; RCC: renal cell cancer; SAT: subcutaneous adiposity tissue; SFA: superficial fat area; SMD: skeletal muscle density; VAT: visceral adiposity tissue.

Antoun et al. (23) evaluated the impact of $\mathrm{CT}$ assessed body composition in a subset of patients from mRCC trials treated with sorafenib, sunitinib, everolimus, and placebo. When adjusted for the IMDC model score, mRCC patients with high SMD had significantly longer OS (HR 1.85; $\mathrm{p}=0.02$ ) and PFS (HR 1.81; $\mathrm{p}=0.02$ ), in contrast to patients with low SMD. Antoun et al. incorporated SMD into the IMDC model 
score and created a new model. Median OS for patients with a favorable-risk IMDC model score and high SMD was 35 months (95\% CI 24-43 months); 22 months (95\% CI 14-27 months) for patients with an intermediate-risk IMDC model score and high SMD as well as a favorable-risk IMDC model score and low SMD; and 8 months (95\% CI 6-12 months) for patients with an intermediate-risk IMDC model score and low SMD. This model has not been externally validated. No relationship was found between BMI and outcomes. SAT and VAT were not prognostic.

\section{The impact of sarcopenia on adverse events from targeted therapy}

Sarcopenia was evaluated in a subset of mRCC patients from the TARGET trial (sorafenib vs placebo after progression on standard therapy) (24). Sarcopenia was present in $72 \%$ of patients with a BMI $<25$ and $34 \%$ of obese patients. Treatment with sorafenib was associated with a significant decrease in skeletal muscle in comparison with placebo $(8.0 \%$ loss, $\mathrm{p}<0.01)$. Preclinical models suggest that the skeletal muscle loss associated with sorafenib may be mediated by downstream effects of mTOR inhibition (25). Frequency of sorafenib-induced doselimiting toxicities was highest in sarcopenic patients whose BMI $<25 \mathrm{~kg} / \mathrm{m}^{2}$, and lowest in nonsarcopenic patients who were overweight or obese $(p=0.03)$ (24). These results suggest that sarcopenia in $\mathrm{mRCC}$ is a predictor of sorafenib-induced toxicity. Since sorafenib promotes muscle loss severe adverse events may be more frequent in sarcopenic patients. A future area of research would be to individualize the dose of a targeted therapy based on a patient's skeletal muscle mass, in order to decrease dose-limiting toxicities and optimize clinical outcomes (23).

A similar interaction between sarcopenia and toxicity was observed in a retrospective analysis of $112 \mathrm{mRCC}$ patients treated with mTOR inhibitors, immunotherapy, VEGF inhibitors, Tyrosine Kinase Inhibitors (TKIs), and best supportive care (26). The prevalence of sarcopenia was $20.5 \%$ at baseline and increased to $38.4 \%$ at the end of the evaluation. Sarcopenia was independently associated with increased frequency of severe (common toxicity criteria grade $>$ 2) treatment toxicity (Pearson chi-square value 12.82; $\mathrm{p}=$ 0.001).

Huillard et al. (27) explored the association between sarcopenia and toxicities in 61 mRCC patients treated with sunitinib. Sarcopenia was present in 32 patients $(52.5 \%)$, and 20 sarcopenic patients $(32.8 \%)$ also had a BMI $<25 \mathrm{~kg} / \mathrm{m}^{2}$. Patients with sarcopenia and $\mathrm{BMI}<25$ $\mathrm{kg} / \mathrm{m}^{2}$ experienced significantly more doselimiting toxicities (DLTs) $(\mathrm{OR}=4.1,95 \% \mathrm{CI}$ $1.3-13.3, p=0.01$ ). During the first cycle, they also experienced more grade 3 toxicities $(\mathrm{p}=0.04)$, as well as more cumulative grade 2 or 3 toxicities $(\mathrm{p}=$ 0.008). Sunitinib was permanently discontinued during the first cycle in 30\% of sarcopenic patients, as compared with $2.4 \%$ of the remaining patients $(\mathrm{p}=0.01)$. On multivariate analysis, the combination of sarcopenia and $\mathrm{BMI}<25 \mathrm{~kg} / \mathrm{m}^{2}$ was the only independent predictor of early DLTs ( $p$ $=0.04)$. However, the presence of sarcopenia had no significant impact on OS $(p=0.75)$ and PFS $(p=0.071)$.

Cushen et al. (28) investigated the impact of fat-free mass and skeletal muscle mass (SMM; metabolic tissues such as the liver and kidney, intracellular and extracellular water, and bone) on DLTs in mRCC patients treated with sunitinib. Sarcopenia was present in $33 \%$ of the patients $(18 / 55)$. DLTs were inversely associated with SMM; $92 \%$ of the patients with SMM $<25$ th percentile experienced DLTs, in contrast to $57 \%$ of those patients with SMM $>75$ th percentile $(p=0.05)$. Patients with low fatfree mass $(n=4)$ experienced significantly more DLTs than those with high fat-free mass $(\mathrm{n}=2, \mathrm{p}=0.002)$, but it is unclear what cutoff was used to determine the differentiation between these two groups.

\section{Discussion}

The IMDC database has the largest series of patients evaluating the impact of BMI on outcomes in mRCC patients treated with targeted therapy. OS was significantly improved in overweight patients $(\mathrm{BMI} \geq 25$ $\mathrm{kg} / \mathrm{m}^{2}$ ), and this observation was externally validated in patients who participated in Pfizer trials $(17,18)$. FASN gene is an emerging oncogene in $\mathrm{mRCC}$, 
and high BMI may be a surrogate for low FASN levels. If this finding is externally validated prospectively, future studies should optimize the FASN assay and determine whether inhibition of this pathway has the potential to improve outcomes for mRCC.

CT may provide a more refined description of body composition than relatively crude measurements such as BMI. The impact of adipose tissue on $\mathrm{mRCC}$ outcomes is unclear. High VFA and SFA were associated with improved OS in studies performed by Steffens et al. (20) and $\mathrm{Gu}$ et al. (22). Conversely, increased VFA was associated with worse outcomes were in Ladoire's cohort (21). Antoun et al. (23) found no association between VFA or SFA and outcomes. Sarcopenia was associated with worse outcomes by Antoun et al. (23), but not in the cohort evaluated by Gu et al. (22). These four cohorts did not observe a significant association of BMI with outcomes, but were all smaller than the IMDC cohort (17). These investigators used different combinations of imaging software programs and anatomical landmarks. Further refinement of this technology is required, and the cutpoints for sarcopenia, VFA, and SFA require further validation in a larger cohort of patients. These studies also focused on baseline measurements of BMI, and SFA and VFA $(17,18,20-23)$. Further studies evaluating the paradox of obesity being a risk factor as wells a prognostic marker of response to targeted therapy are needed.

Toxicity from targeted therapy appears to be independent of BMI $(17,18)$. Retrospective series evaluating sarcopenia consistently demonstrate a relationship between sarcopenia and increased toxicity from targeted agents $(24,26-28)$. These studies were small, and the ideal method for evaluating sarcopenia as well as the optimum cutoff point has yet to be established.

What is the impact of sarcopenia on mRCC patients who are treated with targeted therapy? Sarcopenia is consistently associated with increased toxicity to inhibitors of angiogenesis and mTOR. A structured exercise program and dietary intervention may strengthen patients with mRCC and improve response to targeted therapy. Prospective studies evaluating the impact of diet and exercise on targeted therapy tolerance, quality of life, and body composition are warranted.

Future longitudinal studies should evaluate the prognostic impact of sarcopenia, VAT, SFA, BMI, and BSA in mRCC patients treated with targeted therapy. This would require controlling for other prognostic variables in a very large patient cohort to fully address this issue. This may facilitate the development of more refined prognostic models of mRCC treated with targeted therapy.

\section{Conflict of Interest}

The authors declare no potential conflicts of interest with respect to research, authorship, and/or publication of this article.

\section{References}

1. Heng DY, Xie W, Regan MM, Warren MA, Golshayan AR, Sahi C, et al. Prognostic factors for overall survival in patients with metastatic renal cell carcinoma treated with vascular endothelial growth factortargeted agents: Results from a large, multicenter study. J Clin Oncol. 2009;27:5794-5799. http://dx.doi.org/10.1200/JCO.2008.21.4 $\underline{809}$

2. Motzer RJ, Bacik J, Murphy BA, Russo $\mathrm{P}$, Mazumdar $\mathrm{M}$. Interferon-alfa as a comparative treatment for clinical trials of new therapies against advanced renal cell carcinoma. J Clin Oncol. 2002;20:289-296.

3. Motzer RJ, Mazumdar M, Bacik J, Berg W, Amsterdam A, Ferrara J. Survival and prognostic stratification of 670 patients with advanced renal cell carcinoma. J Clin Oncol. 1999;17:2530-2540.

4. Calle EE, Rodriguez C, WalkerThurmond K, Thun MJ. Overweight, obesity, and mortality from cancer in a prospectively studied cohort of U.S. adults. N Engl J Med. 2003;348:1625-1638. http://dx.doi.org/10.1056/NEJMoa021423

5. Chow WH, Dong LM, Devesa SS. Epidemiology and risk factors for kidney cancer Nat Rev Urol. 2010;7:245-257. http://dx.doi.org/10.1038/nrurol.2010.46 
6. Chow WH, McLaughlin JK, Mandel JS, Wacholder S, Niwa S, Fraumeni JF Jr. Obesity and risk of renal cell cancer Cancer Epidemiol Biomarkers Prev. 1996;5:17-21.

7. Lindblad P, Wolk A, Bergström R, Persson I, Adami HO. The role of obesity and weight fluctuations in the etiology of renal cell cancer: A population-based casecontrol study. Cancer Epidemiol Biomarkers Prev. 1994;3:631-639.

8. World Health Organization. In: Obesity: Preventing and managing the global epidemic. WHO Technical Report Series (894th ed.). Geneva, Switzerland: World Health Organization; 2000.

9. Hursting SD, Berger NA. Energy balance, host-related factors, and cancer progression. J Clin Oncol. 2010;28:40584065.

http://dx.doi.org/ 10.1200/JCO.2010.27.9 $\underline{935}$

10. Ceciliani F, Giordano A, Spagnolo V. The systemic reaction during inflammation: The acute- phase proteins. Protein Pept Lett. 2002;9:211-223.

11. Cao Y. Angiogenesis modulates adipogenesis and obesity $\mathrm{J}$ Clin Invest. 2007;117:2362-2368.

http://dx.doi.org/10.1172/JCI32239

12. Leslie NR. The redox regulation of PI $3-$ kinase-dependent signaling. Antioxid Redox Signal. 2006;8:1765-1774.

http://dx.doi.org/10.1089/ars.2006.8.1 $\underline{765}$

13. Pollak M. Insulin and insulin-like growth factor signalling in neoplasia Nat Rev Cancer. 2008;8:915-928.

http:/ /dx.doi.org/ 10.1038/nrc2536

14. Awakura $\mathrm{Y}$, Nakamura $\mathrm{E}$, Ito $\mathrm{N}$, Yamasaki T, Kamba T, Kamoto $\mathrm{T}$, et al. Influence of body mass index on prognosis of Japanese patients with renal cell carcinoma. Urology. 2007;70:50-54.

http://dx.doi.org/10.1016/j.urology.2007. $\underline{03.034}$

15. Kamat AM, Shock RP, Naya Y, Rosser CJ, Slaton JW, Pisters LL. Prognostic value of body mass index in patients undergoing nephrectomy for localized renal tumors. Urology. 2004;63:46-50.

16. Choueiri TK, Xie W, Kollmannsberger CK, Rini BI, McDermott DF, Knox JJ, et al. The impact of body mass index (BMI) and body surface area (BSA) on treatment outcome to vascular endothelial growth factor (VEGF)-targeted therapy in metastatic renal cell carcinoma: Results from a large international collaboration (abstract 4524). Proc Am Soc Clin Oncol. 2010;28:347s.

17. Albiges LA, Xie W, Lee JL, Rini BI, Srinivas S, Bjarnason GA, et al. The impact of body mass index (BMI) on treatment outcome of targeted therapy in metastatic renal cell carcinoma ( $\mathrm{mRCC})$ : Results from the International Metastatic Renal Cell Cancer Database Consortium. J Clin Oncol. 2014;32(5s):Abstr 4576.

18. Albiges LA, Hakimi AA, Lin X, Simantov $\mathrm{R}$, Zabor EC, Jacobsen A, et al. The impact of BMI on outcomes of patients with metastatic renal cell carcinoma treated with targeted therapy: An external validation data set and analysis of underlying biology from The Cancer Genome Atlas. J Clin Oncol. 2015;33(7):abstr 405.

19. Flavin R, Peluso S, Nguyen PL, Loda M. Fatty acid synthase as a potential therapeutic target in cancer. Future Oncol. 2010;6(4):551-562.

http://dx.doi.org/10.2217/fon.10.11

20. Steffens S, Grunwald V, Ringe K, Seidel C, Eggers H, Schrader M, et al. Does obesity influence the prognosis of metastatic renal cell carcinoma in patients treated with vascular endothelial growth factor-targeted therapy? The Oncologist. 2011;16:1565-1571.

http://dx.doi.org/10.1634/theoncologist.2 011-0213

21. Ladoire S, Bonnetain F, Gauthier M, Zanetta S, Petit JM, Guiu S, et al. Visceral fat area as a new independent predictive factor of survival in patients with metastatic renal cell carcinoma treated with antiangiogenic agents. The Oncologist. 2011;16:71-81.

http://dx.doi.org/10.1634/theoncologist.2 010-0227 
22. Gu W, Zhu Y, Wang H, Zhang H, Shi G, Liu X. Prognostic value of components of body composition in patients treated with targeted therapy for advanced renal cell carcinoma: a retrospective case series. PLoS One. 2015;10(2):e0118022.

http://dx.doi.org/10.1371/journal.pone.0 118022 .

23. Antoun S, Lanoy E, Iacovelli R, AlbigesSauvin L, Loriot Y, Merad-Taoufik M, et al. Skeletal muscle density predicts prognosis in patients with metastatic renal cell carcinoma treated with targeted therapies. Cancer. 2013;119:3377-3384.

http://dx.doi.org/10.1002/cncr.28218

24. Antoun S, Baracos VE, Birdsell L, Escudier B, Sawyer MB. Low body mass index and sarcopenia associated with doselimiting toxicity of sorafenib in patients with renal cell carcinoma. Ann Oncol. 2010;21:1594-1598.

http://dx.doi.org/10.1093/annonc/mdp60 $\underline{5}$

25. Bodine SC, Stitt TN, Gonzalez M, Kline WO, Stover GL, Bauerlein $\mathrm{R}$, et al. Akt/mTOR pathway is a crucial regulator of skeletal muscle hypertrophy and can prevent muscle atrophy in vivo. Nat Cell Biol. 2001;3:1014-1019.

http://dx.doi.org/10.1038/ncb1101$\underline{1014}$

26. McCabe K, Goh V, Vinaya A, Petruckevitch A, Nathan PD. Body composition and association with treatment toxicity in patients with advanced renal cell carcinoma receiving targeted agents. J Clin Oncol. 2013;31 (suppl; abstr e15608).

27. Huillard O, Mir O, Peyromaure M, Tlemsani C, Tlemsani C, Giroux J, BoudouRouquette $\mathrm{P}$, et al. Sarcopenia and body mass index predict sunitinib-induced early dose-limiting toxicities in renal cancer patients. Br J Cancer 2013;108: 1034-1041. http://dx.doi.org/10.1038/bjc. 2013.58

28. Cushen SJ, Power DG, Teo MY, Maceneaney P, Maher MM, McDermott R, et al. Body composition by computed tomography as a predictor of toxicity in patients with renal cell carcinoma treated with sunitinib. Am J Clin Oncol. 2014 April 21. 